\title{
Effect of temperature on the growth, survival, development and foraging behaviour of Sardina pilchardus larvae
}

\author{
S. Garrido ${ }^{1,2, *}$, A. Cristóvão ${ }^{2}$, C. Caldeira ${ }^{2}$, R. Ben-Hamadou ${ }^{3}$, N. Baylina ${ }^{4}$, \\ H. Batista ${ }^{4}$, E. Saiz ${ }^{5}$, M. A. Peck ${ }^{6}$, P. Ré ${ }^{2}$, A. M. P. Santos ${ }^{1,7}$ \\ ${ }^{1}$ Instituto Português do Mar e da Atmosfera, Av. Brasília s/n, 1449-006 Lisboa, Portugal \\ ${ }^{2}$ Marine and Environmental Sciences Centre, Faculdade de Ciências, Universidade de Lisboa, Campo Grande, \\ 1749-016 Lisboa, Portugal
}

${ }^{3}$ Department of Biological and Environmental Sciences, College of Arts and Sciences, Qatar University, PO Box 2713, Doha, Qatar

${ }^{4}$ Oceanário de Lisboa, Esplanada D Carlos I, 1900-005 Lisbon, Portugal

${ }^{5}$ Institut de Ciències del Mar - CSIC, Ps. Marítim de la Barceloneta 37-49, 08003 Barcelona, Spain

${ }^{6}$ Institute for Hydrobiology and Fisheries Science, University of Hamburg, Olbersweg 24, 22767 Hamburg, Germany

${ }^{7}$ CCMAR, Centro de Ciencias do Mar, Universidade do Algarve, Campus de Gambelas, 8005-139 Faro, Portugal

\begin{abstract}
The effect of water temperature on the growth, survival, development and foraging behaviour of European sardine Sardina pilchardus larvae was examined in the laboratory. First, the capability of early sardine larvae to cope with starvation was assessed at temperatures from 10 to $22^{\circ} \mathrm{C}$. Second, we examined under ad libitum feeding conditions and across the range of temperatures experienced by sardines during spawning along the Atlanto-Iberian coast $\left(13-17^{\circ} \mathrm{C}\right)$ the ontogenetic changes in growth, survival and foraging behaviour of sardine larvae. Unfed larvae had similar maximum survival times (11-12 d post hatching, dph) from 13 to $15^{\circ} \mathrm{C}$, but the survival time was significantly shorter at the coldest and warmest temperatures tested. The survival of exogenously feeding larvae increased with temperature, but younger endogenously feeding larvae had higher survival at colder temperatures. The cumulative mortality after $25 \mathrm{dph}$, however, was similar at the 3 temperatures. Not only larval growth rate increased with increasing temperature, but ontogenetic development also occurred sooner and at smaller sizes. Notochord flexion, which is a developmental milestone for fish, occurred $10 \mathrm{~d}$ earlier at 17 rather than at $13^{\circ} \mathrm{C}$. The time spent swimming and the foraging behaviour (orientations to prey, feeding strikes and successful capture) significantly increased throughout the ontogeny and with temperature. This study highlights how even modest changes in spawning temperature can lead to large changes in the survival and growth of larval sardine. This study also reveals some of the mechanisms whereby inter-annual and seasonal variability in temperature can have significant ecological impacts at the population level.
\end{abstract}

KEY WORDS: Sardina pilchardus $\cdot$ Growth rate $\cdot$ Pelagic fish $\cdot$ Mortality $\cdot$ Foraging behaviour

\section{INTRODUCTION}

Temperature influences metabolism and growth in poikilotherms (Clarke \& Johnston 1999) and is considered a key factor shaping the ecophysiology and life history strategy of fish (Pörtner \& Peck 2010).

${ }^{*}$ Corresponding author: garridosus@gmail.com
Temperature plays a particularly important role during the early life of marine fish by influencing rates of metabolism, growth and mortality of marine fish larvae (Houde 1989, Blaxter 1991). The ability of a species, a population or an individual to persist over a range of temperatures is limited by the thermal adap-

(C) The authors 2016. Open Access under Creative Commons by Attribution Licence. Use, distribution and reproduction are unrestricted. Authors and original publication must be credited. 
tive capacity of biochemical, cellular and organismal processes which constrains the geographic distribution of stocks and influences inter-annual variability in survival (Jordaan \& Kling 2003) and also by the severity of climate impacts (Rijnsdorp et al. 2009). Even within the limits of thermal tolerance, subtle changes in temperature experienced by early larvae cannot only influence survival by altering physiological rates and behaviour but can also influence the performance of survivors later in life (Johnston et al. 2001, Koumoundouros et al. 2009, Moyano et al. 2016). Discriminating the relative contribution of genetic versus environmental factors to the variation in larval performance is necessary if we hope to provide robust predictions of the effects of climate change on fish stocks (Jordaan \& Kling 2003, Dahlke et al. 2016).

The European sardine Sardina pilchardus is distributed along the eastern North Atlantic coast, from Iceland and the North Sea to Senegal and the Mediterranean Sea (Whitehead et al. 1985). One of the main areas of sardine spawning in the northeast Atlantic is the Iberian Peninsula, where sardine larvae often dominate the ichthyoplankton community (Garrido et al. 2009). Due to persistently low recruitment since 2006, the size of the Iberian sardine stock has substantially decreased, reaching historical minimum values in 2012-2013 (ICES 2014). The decrease in recruitment of European sardines is thought to be directly related to increasing water temperature observed in recent years in the Western Iberian Up-

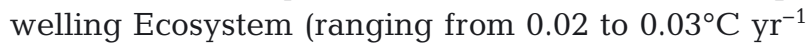
since 1985) (Relvas et al. 2009). Field surveys in that region report the highest occurrence of spawning at 14 to $15^{\circ} \mathrm{C}$ with little or no spawning at water temperatures colder than $12^{\circ} \mathrm{C}$ and warmer than $16^{\circ} \mathrm{C}$ (Stratoudakis et al. 2007, Peck et al. 2013). The sizeat-maturation is generally smaller in sardines from warmer waters and, likely for this reason, length-atmaturation has decreased and the spawning period has increased in western Iberian waters during the last 2 decades (Silva et al. 2006). In order to understand the modifications in sardine spawning and development, it is essential to know the underlying physiological and behavioural responses of individual larvae at different temperatures.

Laboratory studies can serve to simplify some of the interactions of inherently complex natural systems by removing factors that confound temperature effects, such as food limitation (Jordaan \& Kling 2003). To our best knowledge, there are no previous laboratory studies examining ontogenetic changes and/or the effect of temperature on survival, growth and behaviour of exogenously feeding European sar- dine, with all previous studies restricted to either embryos or unfed larvae (Blaxter 1969, Miranda et al. 1990, Bernal et al. 2008). The present study investigated the effect of temperature on the growth, survival and foraging behaviour of European sardine larvae. First, the capacity of larvae to withstand starvation as a function of temperature was assessed. Second, the effect of temperature on growth, mortality and foraging behaviour was studied for larvae reared with excess food across at a range of temperatures encompassing the vast majority (95\%) of those associated with sardine spawning in Atlanto-Iberian waters (Coombs et al. 2006). This study examines the effect of temperature on growth, mortality and foraging behaviour of European sardine larvae under controlled laboratory conditions, and our results are discussed in relation to patterns derived from the field.

\section{MATERIALS AND METHODS}

\section{Larval rearing and growth experiments}

Sardine larvae were hatched from eggs spawned by broodstock European sardines Sardina pilchardus maintained in a $15000 \mathrm{l}$ cylindrical tank at the Oceanário de Lisboa. Fish were originally captured in 2009 and 2010 by purse seine in coastal waters off Peniche (western Portugal). Adult fish started spawning naturally after adjusting the temperature $\left(15^{\circ} \mathrm{C}\right)$ to natural conditions and increasing the light regime (16 $\mathrm{h}$ light:8 $\mathrm{h}$ dark) to the maximum number of daylight hours occurring in western Iberia. The eggs were collected daily in the morning from the broodstock using $500 \mu \mathrm{m}$ mesh egg collector bags placed in the skimmers of the tank. At that time, most eggs were found halfway through egg development (Stage V, Gamulin \& Hure 1955). A total of 2000 viable eggs was placed into $5 \mathrm{l}$ glass beakers containing gently aerated water from the broodstock tank. Over the next 1 to $2 \mathrm{~h}$, the temperature was slowly adjusted to 17,15 or $13^{\circ} \mathrm{C}$. Finally, eggs were gently transferred to $30 \mathrm{l}$ cylindrical tanks filled with seawater of salinity 35 at their rearing temperature. Eggs were incubated using a $16 \mathrm{~h}$ light:8 $\mathrm{h}$ dark light regime and gentle aeration to mix the water and maintain a high oxygen concentration. Surface light levels were kept at 55 to $58 \mu \mathrm{mol} \mathrm{s}{ }^{-1} \mathrm{~m}^{-2}$ (Philips Master TL-D Super 80 58W fluorescent lamp).

Growth experiments consisted of transferring batches of ca. 2000 sardine eggs to the abovementioned $30 \mathrm{l}$ tanks and rearing the embryos and larvae either unfed or fed a mixed diet of dinoflagel- 
lates Gymnodinium sp., rotifers Brachionus sp. and nauplii, copepodites and adults of the copepod Paracartia grani. Details of the feeding conditions, which translate into saturated feeding and growth rates of sardine larvae, can be found in Silva et al. (2014) and Caldeira et al. (2014). Each morning, after checking the food concentration in the tanks, 20 to $30 \%$ of the tank water was renewed by syphoning the bottom of the tank, and new food was added to obtain the preestablished food concentration. Every other day $\mathrm{pH}$, ammonia and oxygen were measured (Hanna Instruments 9828) to confirm that high water quality was maintained throughout the experiment. In the starvation experiment, 5 different temperatures were tested $\left(10,13,15,17\right.$, and $\left.22^{\circ} \mathrm{C} \pm 0.4^{\circ} \mathrm{C}\right)$. Experiments using fed larvae were conducted at 13,15 and $17^{\circ} \mathrm{C}$, which correspond to the coldest, peak and warmest temperatures, respectively, measured during peak spawning by sardines in Iberian waters (Coombs et al. 2006).

Throughout the experiment, groups of larvae were randomly sampled from experimental tanks and rapidly anesthetized with MS-222 to determine their size (total length, TL) under a stereomicroscope $( \pm 0.05 \mathrm{~mm}$ accuracy) and posteriorly preserved in formaldehyde. When embryos were found to be in an advanced developmental stage (Stage $X_{i}$ Gamulin \& Hure 1955), tanks were inspected frequently to determine the time when $50 \%$ of the larvae hatched. Larval size was determined at the time when $\sim 50 \%$ of the larvae had hatched. Given that at the temperatures tested the hatching period can last up to $10 \mathrm{~h}$ (Bernal et al. 2008), larval size-at-hatch would be temperaturedependently overestimated, and for that reason larval size at the day of hatching was not formally compared between temperatures. Larvae were sampled from each tank each day until death in the case of unfed larvae. In the case of fed larvae, samples were taken until $50 \mathrm{~d}$ post-hatching (dph) at 15 and $17^{\circ} \mathrm{C}$ and at $25 \mathrm{dph}$ at $13^{\circ} \mathrm{C}$, where technical problems did not allow measurements beyond that age due to accidental loss of larvae. Mean larval TL for fed larvae was determined from measurements made on 20 (at hatching), $\geq 10$ (3 to $15 \mathrm{dph}$ ) and 5-10 ( $\geq 16 \mathrm{dph}$ ) individuals. Measurements of sardine larvae were made at 0,3 , and $5 \mathrm{dph}$ and then every $5 \mathrm{~d}$ until the end of the experiment. Every day, the bottom of each tank was syphoned, and dead larvae were counted to determine age-specific survival rates.

Sardine larvae preserved in formaldehyde were digitally photographed under a stereoscope (Leica S8 APO, zoom 8:1 with a Canon EOS SLR550 camera), and the development of important ontogenetic traits of fish larvae, such as fin formation and notochord flexion, were registered for larvae reared at each of the 3 temperatures.

\section{Foraging behaviour}

The behaviour of fed larvae was observed at 3 temperatures $\left(13,15\right.$ and $\left.17^{\circ} \mathrm{C}\right)$. Every day and for each temperature treatment, randomly selected larvae ( $\geq 20$ observations) were individually followed and their behaviour registered for a 1 min interval (focalanimal technique, Martin \& Bateson 1993). During observations, water mixing was stopped by removing the aeration so that individual larvae could be followed in the absence of turbulence which may affect larval behaviour. The time spent swimming by the larvae during the 1 min observation period (locomotory model action pattern), as an indicator of foraging effort, was logged. The foraging MAPs recorded, adapted from Barlow (1968), included the occurrence of orientations (also termed fixations or s-shape positions when detecting a prey) and the frequency of lunges or attacks on prey; given that not all orientations resulted in successful attacks, the percentage of complete feeding sequences with respect to the total number of orientations was also estimated. At 15 and $17^{\circ} \mathrm{C}$, behavioural observations were made until the larvae were 50 and $25 \mathrm{dph}$ at $13^{\circ} \mathrm{C}$.

\section{Data analysis}

For fed larvae from 3 to $25 \mathrm{dph}$ at each of the 3 temperature treatments, growth rate was assessed from the exponential fit of TL (in $\mathrm{mm}$ ) and age data using the equation:

$$
\mathrm{TL}=L_{0} \mathrm{e}^{k t}
$$

where $L_{0}$ is length at $3 \mathrm{dph}, k$ is the instantaneous growth rate and $t$ is age in $\mathrm{dph}$. In the case of larvae reared until $50 \mathrm{dph}$ at 15 and $17^{\circ} \mathrm{C}$, data were adjusted from 3 to $50 \mathrm{dph}$ to a Laird-Gompertz growth curve by an iterative nonlinear regression routine:

$$
\mathrm{TL}=L_{0} \mathrm{e}^{\left(\frac{A_{0}}{\alpha}\right)\left(1-\mathrm{e}^{-\alpha t}\right)}
$$

where $A_{0}$ is the growth rate at time 0 , and $\alpha$ is the rate of exponential decay.

To compare the relationship between size and age between larvae reared at different temperatures from age 3 to age $25 \mathrm{dph}$ (common range in ages between the 3 temperatures), first generalized linear models (GLMs) with an identity link were used to as- 
sess if the interactions of age and temperature were significant. When the interaction term was significant, pairwise comparisons of slopes were conducted using an ANCOVA model. When the differences between the slopes were significant, the regression was repeated excluding the interaction term. When the differences between the slopes were not significant, a new regression model excluding the interaction term was fitted, and both regression models (with and without the interaction model) were compared using ANOVA, and then the most parsimonious model was selected. Growth rates of 3 to $50 \mathrm{dph}$ larvae reared at 15 and $17^{\circ} \mathrm{C}$ and fitted to Laird-Gompertz growth curves were compared by using the method to compare non-linear models described in Chen et al. (1992).

Cumulative survival rates of sardine larvae reared with excess food were calculated from Day 0 to $25 \mathrm{dph}$. Comparison of the survival rates of larvae reared with different temperatures was conducted using the Logrank (Mantel cox) $z$-test. Cumulative survival rates were considered different when $\mathrm{p}<0.05$.

GLMs were used to test the significance of the interaction between age and temperature on the time spent swimming, the number of orientations, number of attacks on prey and the percentage of successful attacks on prey for pre-flexion sardine larvae $(\leq 25 \mathrm{dph}$ for larvae reared at 13 and $15^{\circ} \mathrm{C}$ and $\leq 20 \mathrm{dph}$ for larvae reared at $17^{\circ} \mathrm{C}$ ). When the interaction term was significant, pairwise comparisons of slopes were conducted using an ANCOVA model. When the differences between the slopes were significant, the regressions were repeated excluding the interaction term. When the differences between the slopes were not significant, a new regression model excluding the interaction term was fitted and both regression models (with and without the interaction model) were compared using ANOVA, and then the most parsimonious model was selected.

Foraging efficiency (FE) was estimated as

$$
\mathrm{FE}=K \times 100 / C
$$

where $K$ is the growth rate of sardine larvae and $C$ is the capture rate (here estimated as the number of attacks on prey) at each of the 3 temperatures. Both $K$ and $C$ were expressed in carbon units ( $\mu \mathrm{g} C$ ) by using available conversions of larvae length to carbon content and prey mean length of prey (Paracartia grani) to carbon content (Caldeira et al. 2014). Statistical analyses were performed using Matlab 8.1 (R2013a) from Mathworks (mortality data) and the open source software R version 2.9.2 of R Development Core Team (growth and behavioural data).

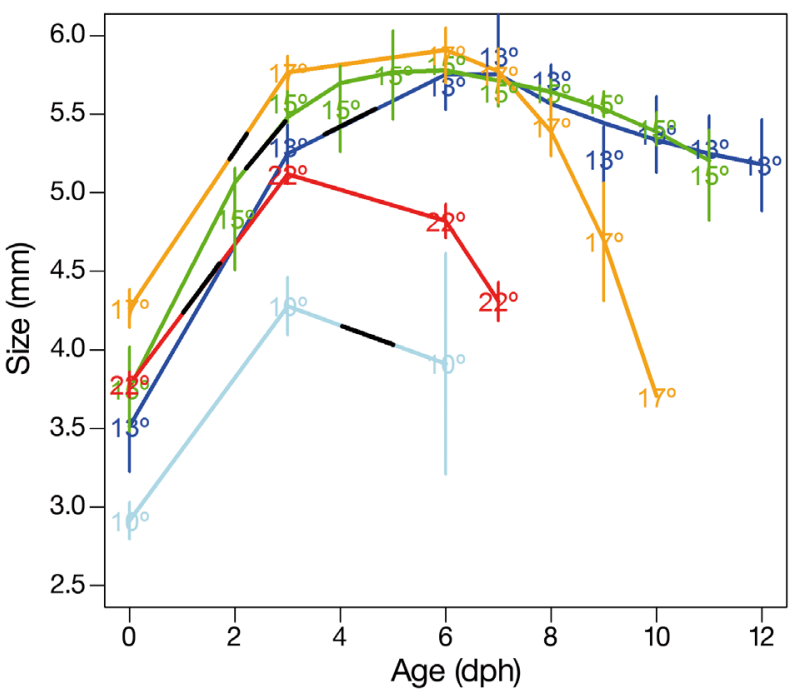

Fig. 1. Mean size-at-age (total length $\pm \mathrm{SE}, \mathrm{mm})$ versus age $(\mathrm{d}$ post-hatching, dph) of unfed European sardine larvae at 5 different temperatures. Black lines represent the interval at which the yolk sac was exhausted and eyes were pigmented. Mean sizeat-age at age 0 corresponds to the mean size when $50 \%$ of the larvae have hatched in the tank, not the precise size-at-hatch

\section{RESULTS}

\section{Larval growth under starvation}

Sardine larvae hatched sooner at higher temperatures, and the time between egg collection to $50 \%$ hatch ranged from ca. 72 to $30 \mathrm{~h}$ at incubation temperatures of 10 and $22^{\circ} \mathrm{C}$, respectively. The mean $( \pm \mathrm{SD}) \mathrm{TL}$ at the time of $50 \%$ hatch was $2.9 \pm 0.3,3.6$ $\pm 0.3,3.8 \pm 0.7,4.3 \pm 0.3 \mathrm{~mm}$ and $3.8 \pm 0.2 \mathrm{~mm}$ at 10 , $13,15,17$ and $22^{\circ} \mathrm{C}$, respectively. Time until the yolksac absorption and the larvae started exogenous feeding was $2.5 \mathrm{~d}$ at $22^{\circ} \mathrm{C}$ and $4.5 \mathrm{~d}$ at $10^{\circ} \mathrm{C}$.

The growth of endogenously feeding (yolk sac) larvae increased with increasing temperature except at the lowest $\left(10^{\circ} \mathrm{C}\right)$ and highest $\left(22^{\circ} \mathrm{C}\right)$ temperatures. At $10^{\circ} \mathrm{C}$, larval length-at-age remained fairly constant until death and only increased from 0 to $3 \mathrm{dph}$ at $22^{\circ} \mathrm{C}$, sharply decreasing afterwards. At the other 3 temperatures tested, larval size increased until 6-7 dph and then either abruptly dropped $\left(17^{\circ} \mathrm{C}\right)$ or steadily declined $\left(13^{\circ}\right.$ and $15^{\circ} \mathrm{C}$ ) (Fig. 1). Maximum duration of survival of unfed larvae was $6,12,11,12$ and $7 \mathrm{dph}$ at 10, 13, 15, 17 and $22^{\circ} \mathrm{C}$, respectively (Fig. 1).

\section{Growth and survival of feeding larvae}

The batches of sardine larvae used in feeding trials hatched approximately 60, 48 and $30 \mathrm{~h}$ after the em- 

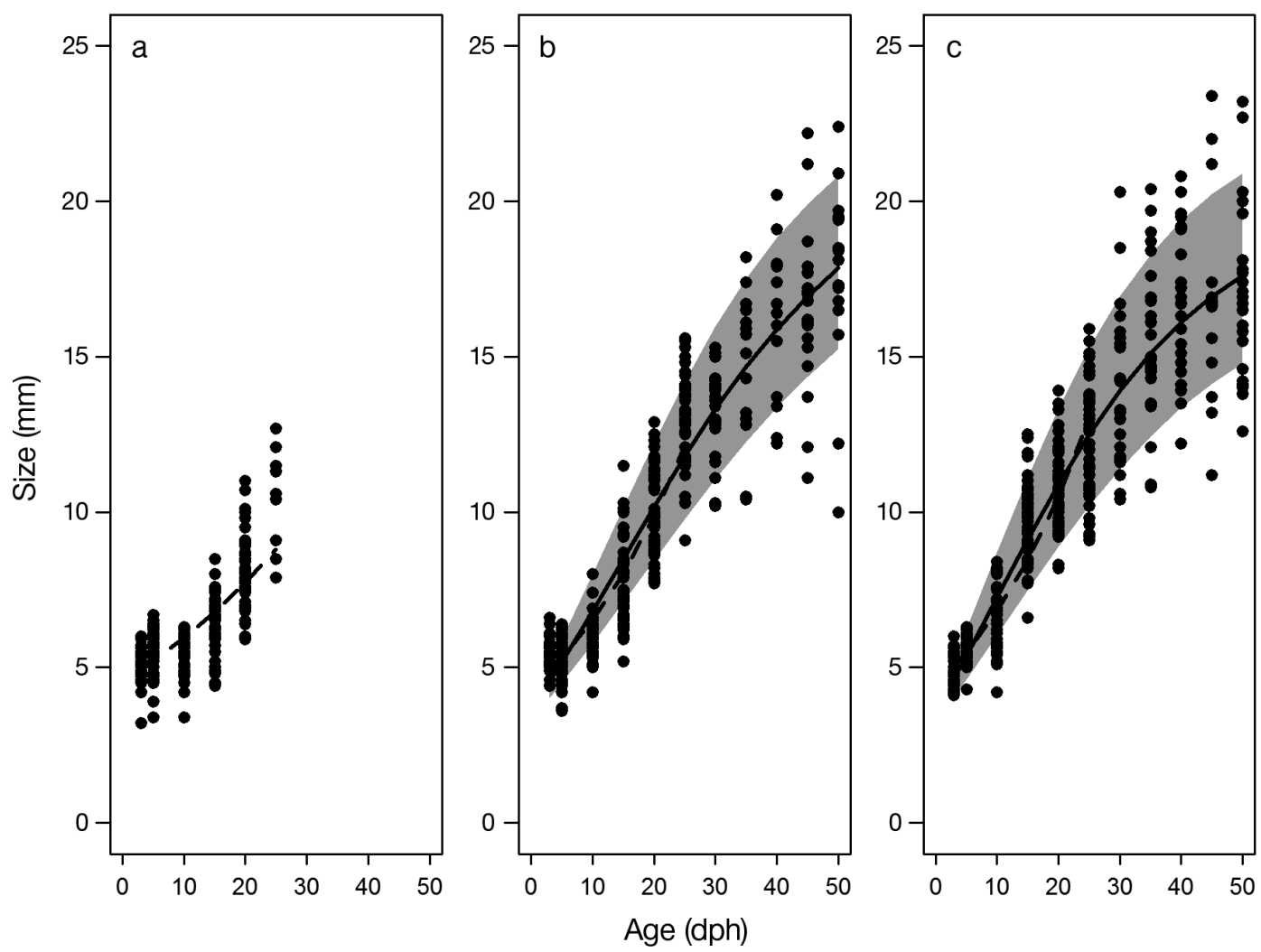

Fig. 2. Total length $(\mathrm{mm})$ versus age (d post-hatching, dph) of fed European sardine larvae at 3 different temperatures: (a) $13^{\circ} \mathrm{C}$, (b) $15^{\circ} \mathrm{C}$, (c) $17^{\circ} \mathrm{C}$. Exponential growth curve fitted for the period from 3 to 25 dph for all temperatures (dashed line). Grey area represents the $95 \%$ confidence interval of the Laird-Gompertz curve fitted to the period from 3 to 50 dph for larvae reared at 15 and $17^{\circ} \mathrm{C}$

bryos were collected from the adult spawning tank, at 13,15 and $17^{\circ} \mathrm{C}$, respectively. There was a significant increase in size (TL) with age with increasing temperature (Fig. 2, Tables 1-3). The GLM model showed a significant effect of temperature on growth for larvae growing from 3 to $25 \mathrm{dph}$ at 13,15 and $17^{\circ} \mathrm{C}$ (Akaike's information criterion $[\mathrm{AIC}]=2694.8$; $\mathrm{p}<0.0001$ ). The exponential increase in larval size from 3 to $25 \mathrm{dph}$ (slope) was similar for larvae reared at 17 and $15^{\circ} \mathrm{C}$ and higher than that of larvae reared at $13^{\circ} \mathrm{C}$ (Tables $1 \& 2$ ). The ANOVA model compar-
Table 1. Results of ANCOVA models analysing the relationship between larval size (total length, $\mathrm{mm}$ ) and age (d post hatching, dph) for Sardina pilchardus larvae reared from 3 to $25 \mathrm{dph}$ at 13,15 and $17^{\circ} \mathrm{C}$

\begin{tabular}{|c|c|c|c|c|c|c|}
\hline \multirow{2}{*}{$\begin{array}{l}\text { Temp. } \\
\left({ }^{\circ} \mathrm{C}\right)\end{array}$} & \multirow[t]{2}{*}{$\mathrm{df}$} & \multicolumn{2}{|c|}{$\longrightarrow$-value -} & \multirow[t]{2}{*}{$F$} & \multirow[t]{2}{*}{$\rho$} & \multirow[t]{2}{*}{$\mathrm{R}^{2}$} \\
\hline & & Intercept & Slope & & & \\
\hline 13 and 15 & 1 & $<0.001$ & 0.001 & 941 & $<0.001$ & 0.81 \\
\hline 13 and 17 & 1 & 0.023 & $<0.001$ & 1033 & $<0.001$ & 0.82 \\
\hline 15 and 17 & 1 & 0.005 & 0.714 & 1710 & $<0.001$ & 0.88 \\
\hline
\end{tabular}

Table 2. Exponential regression of the relationship between larval size (total length, mm) and age (d post hatching, dph) for Sardina pilchardus larvae reared at 13,15 and $17^{\circ} \mathrm{C}$ from 3 to $25 \mathrm{dph}$

\begin{tabular}{|c|c|c|c|c|c|c|c|}
\hline \multirow[t]{3}{*}{ Period } & \multirow{3}{*}{$\begin{array}{l}\text { Temp. } \\
\left({ }^{\circ} \mathrm{C}\right)\end{array}$} & \multirow{3}{*}{$\begin{array}{l}\text { Regression } \\
\text { equation }\end{array}$} & \multirow{3}{*}{$\begin{array}{l}\text { No. of } \\
\text { ind. }\end{array}$} & \multirow{2}{*}{\multicolumn{2}{|c|}{$\begin{array}{l}\text { Confidence interval } \\
\text { (95\% confidence bounds) }\end{array}$}} & \multicolumn{2}{|c|}{ Goodness of fit } \\
\hline & & & & & & Adjusted $\mathrm{R}^{2}$ & One-tailed prob- \\
\hline & & & & Slope & Intercept & & ability (p-value) \\
\hline \multirow[t]{3}{*}{$3-25 \mathrm{dph}$} & 13 & $y=4.12 \mathrm{e}^{0.0258 \mathrm{age}}$ & 257 & $0.0231-0.0286$ & $4.44-4.77$ & 0.58 & $<0.001$ \\
\hline & 15 & $y=4.12 \mathrm{e}^{0.0416 \mathrm{age}}$ & 291 & $0.0395-0.0437$ & $4.16 \pm 4.43$ & 0.84 & $<0.001$ \\
\hline & 17 & $y=4.32 \mathrm{e}^{0.0433 \text { age }}$ & 292 & $0.0412-0.0453$ & $4.28-4.55$ & 0.85 & $<0.001$ \\
\hline
\end{tabular}


Table 3. Relationship between larval size (total length, $\mathrm{mm}$ ) and age (d post hatching, dph) for Sardina pilchardus larvae reared at 15 and $17^{\circ} \mathrm{C}$ from 3 to $50 \mathrm{dph}$ adjusted to a Laird-Gompertz growth curve. $t$ : age in dph; $L_{0}:$ length at 3 dph; $\alpha$ and r: coefficient of the Laird-Gompertz growth curve (Eq. 2)

\begin{tabular}{|lcccccc|}
\hline Period & Temp. $\left({ }^{\circ} \mathrm{C}\right)$ & Regression equation & No. of ind. & \multicolumn{3}{c|}{ Confidence interval (95\% confidence bounds) } \\
& & & & $L_{0}$ & \multicolumn{2}{c}{ r } \\
\hline $3-50 \mathrm{dph}$ & 15 & $\mathrm{TL}=3.68 \mathrm{e}^{\left(\frac{0.074}{0.041}\right)\left(1-\mathrm{e}^{-0.041 t}\right)}$ & 386 & $3.52-4.02$ & $0.064-0.086$ & $0.035-0.047$ \\
& 17 & $\mathrm{TL}=3.86 \mathrm{e}^{\left(\frac{0.081}{0.048}\right)\left(1-\mathrm{e}^{-0.048 t}\right)}$ & 403 & $3.30-4.03$ & $0.074-0.101$ & $0.044-0.058$ \\
\hline
\end{tabular}

ing the regressions with and without the interaction term of age and temperature for larvae reared at 15 and $17^{\circ} \mathrm{C}$ from 3 to 25 dph showed that removing the interaction did not significantly affect the fit of the model $(F=0.13 ; \mathrm{p}=0.71)$, suggesting that exposure temperature did not significantly alter the growth rate of larvae for this age interval. The regression of larval size depending of larval age and temperature without an interaction term for larvae reared at 15 and $17^{\circ} \mathrm{C}$ from 3 to $25 \mathrm{dph}$ showed that the intercept was significantly different for larvae reared at the 2 temperatures $(F=24.77 ; \mathrm{p}<0.0001)$; therefore, sizeat-age was significantly higher for larvae reared at $17^{\circ} \mathrm{C}$.

Growth rates of larvae reared from 3 to $50 \mathrm{dph}$ at 15 and $17^{\circ} \mathrm{C}$ were significantly different $(F=5.76$; $\mathrm{p}>$ 0.0001 ), and larval growth rate was higher for larvae reared at the higher temperature (Fig. 2, Table 3). Cumulative survival rates were significantly different between 13 and $15^{\circ} \mathrm{C}(z=4.75, \mathrm{p}<0.001)$, between 13 and $17^{\circ} \mathrm{C}(z=5.26, \mathrm{p}<0.001)$ and between 15 and $17^{\circ} \mathrm{C}(z=2.04, \mathrm{p}=0.041<0.05)$ (Fig. 3). Mor-

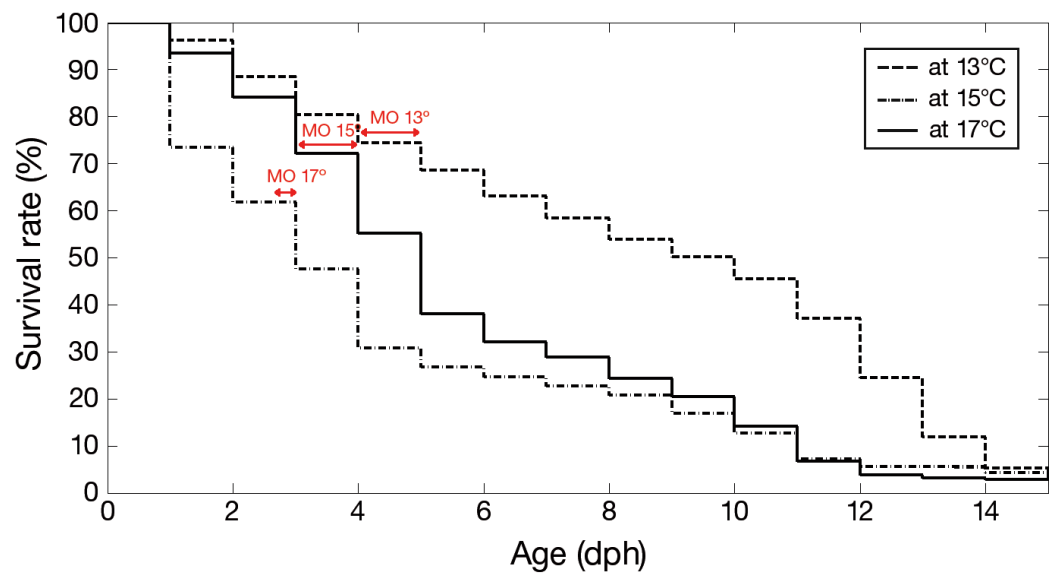

Fig. 3. Cumulative survival rate of Sardina pilchardus larvae reared with high concentration diet and under 3 different temperatures using the Kaplan-Meier method. Survival data not shown after $15 \mathrm{~d}$ post-hatching (dph) as subsequent changes were negligible $(<3 \%)$. Red arrows represent the time period when the mouth opens (MO) and exogenous feeding begins tality during the endogenous feeding stage increased with increasing temperature, but when exogenous feeding was the only feeding mode used by the larvae (>5 dph), daily mortality was significantly higher at lower temperatures. From 12 dph (for 15 and $17^{\circ} \mathrm{C}$ ) and $15 \mathrm{dph}$ (for $13^{\circ} \mathrm{C}$ ) onwards, daily mortality was extremely low when compared to the first days after hatch (Fig. 3).

The development was faster at warmer temperatures. In general, fin formation occurred earlier and at smaller sizes with increasing temperature (Table 4). At $10 \mathrm{dph}$, the pectoral and caudal fins were first observed at $10 \mathrm{dph}$ for larvae reared at 13 and $15^{\circ} \mathrm{C}$ and at $5 \mathrm{dph}$ for larvae reared at $17^{\circ} \mathrm{C}$. The beginning of notochord flexion was observed at 10, 15 and $20 \mathrm{dph}$, for larvae reared at 13,15 and $17^{\circ} \mathrm{C}$, respectively, and the complete flexion occurred at 25 and $20 \mathrm{dph}$ for larvae reared at 15 and $17^{\circ} \mathrm{C}$, respectively. Not only did notochord flexion occur earlier in time for higher temperatures, it also occurred at smaller sizes. At $13^{\circ} \mathrm{C}$, notochord flexion was not complete by the end of the observations (at $25 \mathrm{dph}$ ). Development of the caudal fin was complete at $40 \mathrm{dph}$ (16.2 mm TL) and $30 \mathrm{dph}$ (13.7 mm TL) for larvae reared at 15 and $17^{\circ} \mathrm{C}$, respectively.

\section{Locomotory behaviour and foraging of well-fed larvae}

At 13,15 and $17^{\circ} \mathrm{C}, 1$ to 2 dph sardine larvae spent most of their time inactive, at the surface or near the bottom of the tank. Older larvae started swimming horizontally and vertically, spending most of the time in the upper half of the tank until $25 \mathrm{dph}$ and near the bottom half of the tank at ages $>25 \mathrm{dph}$. Prior to an age of $25 \mathrm{dph}$, larvae paused frequently to search for prey while from approximately $25 \mathrm{dph}$ onwards, larvae 
Table 4. Timing of the main morphological events occurring during larval development of sardine Sardina pilchardus at 13,15 and $17^{\circ} \mathrm{C}$. Pigmentation refers to the appearance of many small scattered melanophores in the dorsal region extending from the head to the tail, with one ventral caudal melanophore. Pectoral fins refer to the time when the insertion of the pectoral fins become oblique. Caudal fin complete refers to the time when the caudal fin has the complete number of fin rays. dph: d post hatching ${ }_{i}-$ : no data

\begin{tabular}{|c|c|c|}
\hline Temp. $\left({ }^{\circ} \mathrm{C}\right)$ & Age (dph) & Mean size $\pm \mathrm{SD}(\mathrm{mm})$ \\
\hline \multicolumn{3}{|c|}{ Hatching day, no pigmentation } \\
\hline 13 & 0 & $3.6 \pm 0.64$ \\
\hline 15 & 0 & $3.8 \pm 0.27$ \\
\hline 17 & 0 & $4.1 \pm 0.34$ \\
\hline \multicolumn{3}{|c|}{ Pigmentation, yolk sac, mouth open } \\
\hline 13 & $4 / 5$ & $5.5 \pm 0.63$ \\
\hline 15 & $3 / 4$ & $5.4 \pm 0.41$ \\
\hline 17 & 3 & $5.0 \pm 0.49$ \\
\hline \multicolumn{3}{|c|}{ Pectoral fins and beginning of caudal fin formation } \\
\hline 13 & 10 & $5.5 \pm 0.60$ \\
\hline 15 & 10 & $5.9 \pm 0.60$ \\
\hline 17 & 5 & $5.5 \pm 0.41$ \\
\hline \multicolumn{3}{|c|}{ Beginning of notochord flexion } \\
\hline 13 & 20 & $8.1 \pm 1.32$ \\
\hline 15 & 15 & $7.7 \pm 1.29$ \\
\hline 17 & 10 & $6.3 \pm 0.92$ \\
\hline \multicolumn{3}{|c|}{ Beginning of dorsal fin development } \\
\hline 13 & 20 & $8.1 \pm 1.32$ \\
\hline 15 & 20 & $10.0 \pm 1.41$ \\
\hline 17 & 15 & $9.7 \pm 1.26$ \\
\hline \multicolumn{3}{|c|}{ Notochord flexion complete } \\
\hline 13 & - & - \\
\hline 15 & 25 & $13.1 \pm 1.52$ \\
\hline 17 & 20 & $10.8 \pm 1.25$ \\
\hline \multicolumn{3}{|c|}{ Dorsal fin complete } \\
\hline 13 & - & - \\
\hline 15 & 30 & $13.2 \pm 1.25$ \\
\hline 17 & 25 & $12.1 \pm 1.82$ \\
\hline \multicolumn{3}{|c|}{ Beginning of anal fin development } \\
\hline 13 & - & - \\
\hline 15 & 35 & $14.5 \pm 2.29$ \\
\hline 17 & 25 & $12.1 \pm 1.82$ \\
\hline \multicolumn{3}{|c|}{ Caudal fin complete } \\
\hline 13 & - & - \\
\hline 15 & 40 & $16.2 \pm 2.49$ \\
\hline 17 & 30 & $13.7 \pm 2.44$ \\
\hline
\end{tabular}

started searching for prey while swimming. Time spent swimming by pre-flexion sardine larvae increased significantly with age, and its interaction with temperature was also significant (GLM AIC = 6995; $\mathrm{p}<0.0001$ ) (Tables $5 \& 6$, Fig. 4). The rate of increase in time spent swimming was higher for larvae reared at $17^{\circ} \mathrm{C}$ when compared to those reared at 13 and $15^{\circ} \mathrm{C}$. The ANOVA testing for differences between the regression models with and without the interaction term of temperature and age for larvae reared at 13 and $15^{\circ} \mathrm{C}$ were not significant $(F=0.846 ; \mathrm{p}=0.357)$, suggesting that the rate of increase in swimming with pre-flexion larvae age was similar for larvae reared at these 2 temperatures. However, the intercept was significantly different between the two $(F=393$; p < $\left.0.0001 ; \mathrm{R}^{2}=0.39\right)$; therefore, the time spent swimming at age was higher at $15^{\circ} \mathrm{C}$.

At the start of exogenous feeding (3 to $5 \mathrm{dph}$ ), foraging activity was low; the (mean \pm SD) frequency of orientation was $0.19 \pm 0.54,0.79 \pm 1.36$, and $1.75 \pm$ 1.99 prey $\mathrm{min}^{-1}$ for larvae reared at 13,15 and $17^{\circ} \mathrm{C}$, respectively. The frequency of attacks (lunges) for first-feeding larvae was $0.09 \pm 0.31,0.40 \pm 0.95$ and $0.81 \pm 1.24$ attacks $\min ^{-1}$ at 13,15 and $17^{\circ} \mathrm{C}$, respectively (Fig. 4). Foraging activity significantly increased with increasing age for pre-flexion larvae, and temperature significantly affected the slope of the increase in the frequency of larval orientations or fixations to prey $(\mathrm{AIC}=8573 ; \mathrm{p}<0.0001)$, attacks on prey $(\mathrm{AIC}=6995 ; \mathrm{p}<0.0001)$ and percentage of successful attacks on prey (AIC $=16776 ; \mathrm{p}<0.0001)$. The slope of the relationship between these 3 foraging behaviours with age increased with increasing temperature, with $13<15<17^{\circ} \mathrm{C}$, except for the slope of the percentage of successful attacks to prey, which was significantly higher at 15 than at $17^{\circ} \mathrm{C}$ (Tables $5 \& 6$ ).

After flexion and dorsal fin began to develop (25 dph for 13 and $15^{\circ} \mathrm{C}, 20 \mathrm{dph}$ for $17^{\circ} \mathrm{C}$, Table 4), time spent swimming was significantly different according to the temperatures with which larvae were reared (ANOVA, $F=8.2 ; \mathrm{p}=0.0005$ ) and was particularly high at $17^{\circ} \mathrm{C}$ and similar between 13 and $15^{\circ} \mathrm{C}$ (p-values of Tukey-test pairwise comparisons of 0.57 , 0.001 and 0.02 for $13-15,13-17$ and $15-17^{\circ} \mathrm{C}$, respectively). Orientations towards prey as well as attacks on prey were also significantly different between temperatures during the flexion stage (ANOVA tests: $F=12.1$ and $4.6 ; \mathrm{p}<0.0001$ and 0.012 , for comparisons of orientations and attacks, respectively). Orientations to prey at this stage were lower at $13^{\circ} \mathrm{C}$ and similar between 15 and $17^{\circ} \mathrm{C}$ (p-values of Tukeytest pairwise comparisons of $0.001,<0.0001$ and 0.238 for $13-15,13-17$ and $15-17^{\circ} \mathrm{C}$, respectively). Attacks on prey were also lower at $13^{\circ} \mathrm{C}$ and similar between 15 and $17^{\circ} \mathrm{C}$ (p-values of Tukey-test pairwise comparisons of $0.002,0.015$ and 0.990 for $13-15,13-17$ and $15-17^{\circ} \mathrm{C}$, respectively). The successful attacks on prey were not significantly different between the 3 temperatures (ANOVA; $F=0.99 ; \mathrm{p}=0.376$ ).

Larvae reached $50 \%$ of their maximal value of time spent swimming at an age of 5.3 and $14.7 \mathrm{dph}$ at 17 and $15^{\circ} \mathrm{C}$, respectively (Fig. 4, Table 7). At approximately 15 and $20 \mathrm{dph}$ for 17 and $15^{\circ} \mathrm{C}$, respectively, sardine larvae spend all the observational time swimming, presenting a constant swimming behaviour. 
Table 5. Results of the linear regression analyses $(y=a x+b)$ of the effect of age (d post hatching, dph) on the time spent swimming (SWI,\%), frequency of orientations (Orient.), frequency of attacks and frequency of successful attacks on prey of Sardina pilchardus larvae during 3 developmental stages: pre-flexion (from 3 to $25 \mathrm{dph}$ at 13 and $15^{\circ} \mathrm{C}$ and from 3 to 20 at $17^{\circ} \mathrm{C}$ ) and post-flexion (25 to $50 \mathrm{dph}$ at $15^{\circ} \mathrm{C}$ and 20 to $50 \mathrm{dph}$ at $17^{\circ} \mathrm{C}$ ) and after caudal fin formation $\left(40 \mathrm{dph}\right.$ at $15^{\circ} \mathrm{C}$ and $50 \mathrm{dph}$ at $17^{\circ} \mathrm{C}$ )

\begin{tabular}{|c|c|c|c|c|c|c|}
\hline Developmental stage & Relation & Temp. $\left({ }^{\circ} \mathrm{C}\right)$ & $a( \pm \mathrm{SE})$ & $b( \pm \mathrm{SE})$ & $\mathrm{p}$ & $\mathrm{R}^{2}$ \\
\hline \multirow[t]{12}{*}{ Pre-flexion } & SWI vs. Age & 13 & $0.029 \pm 0.002$ & $0.15 \pm 0.024$ & $<0.001$ & 0.30 \\
\hline & & 15 & $0.027 \pm 0.001$ & $0.30 \pm 0.020$ & $<0.001$ & 0.37 \\
\hline & & 17 & $0.038 \pm 0.01$ & $0.31 \pm 0.001$ & $<0.001$ & 0.47 \\
\hline & Orient. vs. Age & 13 & $0.09 \pm 0.011$ & $0.28 \pm 0.159$ & $<0.001$ & 0.11 \\
\hline & & 15 & $0.28 \pm 0.017$ & $-0.67 \pm 0.277$ & $<0.001$ & 0.27 \\
\hline & & 17 & $0.50 \pm 0.034$ & $-0.26 \pm 0.417$ & $<0.001$ & 0.32 \\
\hline & Attacks vs. Age & 13 & $0.02 \pm 0.005$ & $0.12 \pm 0.069$ & $<0.001$ & 0.05 \\
\hline & & 15 & $0.17 \pm 0.013$ & $-0.77 \pm 0.207$ & $<0.001$ & 0.20 \\
\hline & & 17 & $0.24 \pm 0.034$ & $-0.29 \pm 0.417$ & $<0.001$ & 0.27 \\
\hline & Success attacks vs. Age & 13 & $0.58 \pm 0.235$ & $14.15 \pm 3.217$ & 0.01 & 0.01 \\
\hline & & 15 & $1.73 \pm 0.013$ & $10.15 \pm 0.207$ & $<0.001$ & 0.11 \\
\hline & & 17 & $1.34 \pm 0.283$ & $24.72 \pm 3.445$ & $<0.001$ & 0.05 \\
\hline \multirow[t]{8}{*}{ Post-flexion } & SWI vs. Age & 15 & $0.002 \pm 0.0004$ & $0.88 \pm 0.015$ & $<0.001$ & 0.06 \\
\hline & & 17 & $-0.0001 \pm 9 \times 10^{-5}$ & $0.99 \pm 0.0032$ & 0.196 & 0.001 \\
\hline & Orient. vs. Age & 15 & $0.35 \pm 0.031$ & $-1.20 \pm 1.194$ & $<0.001$ & 0.16 \\
\hline & & 17 & $0.08 \pm 0.038$ & $12.66 \pm 1.319$ & 0.033 & 0.01 \\
\hline & Attacks vs. Age & 15 & $0.36 \pm 0.028$ & $-5.07 \pm 1.051$ & $<0.001$ & 0.204 \\
\hline & & 17 & $0.12 \pm 0.033$ & $6.63 \pm 1.154$ & $<0.001$ & 0.023 \\
\hline & Success attacks vs. Age & 15 & $1.30 \pm 0.124$ & $14.83 \pm 4.682$ & $<0.001$ & 0.145 \\
\hline & & 17 & $0.54 \pm 0.033$ & $46.61 \pm 1.154$ & $<0.001$ & 0.03 \\
\hline \multirow[t]{8}{*}{ Caudal fin formation } & SWI vs. Age & 15 & $-0.0001 \pm 0.006$ & $1.00 \pm 0.316$ & 0.09 & 0.01 \\
\hline & & 17 & $0.0002 \pm 0.012$ & $0.98 \pm 0.513$ & 0.302 & 0.0001 \\
\hline & Orient. vs. Age & 15 & $0.35 \pm 0.145$ & $-1.67 \pm 6.637$ & 0.014 & 0.021 \\
\hline & & 17 & $0.001 \pm 0.079$ & $16.14 \pm 3.160$ & 0.982 & -0.002 \\
\hline & Attacks vs. Age & 15 & $0.326 \pm 0.133$ & $-3.67 \pm 6.115$ & 0.015 & 0.020 \\
\hline & & 17 & $-0.06 \pm 0.069$ & $14.77 \pm 2.774$ & 0.352 & -0.003 \\
\hline & Success attacks vs. Age & 15 & $0.91 \pm 0.447$ & $31.85 \pm 21.843$ & 0.056 & 0.011 \\
\hline & & 17 & $0.06 \pm 0.246$ & $66.71 \pm 9.807$ & 0.782 & -0.002 \\
\hline
\end{tabular}

Table 6. Results of ANCOVA models analysing the relationship between foraging behaviour (time spent swimming [SWI, \%], frequency of orientations, frequency of attacks and frequency of successful attacks on prey) and Age (d post hatching, dph) of Sardina pilchardus larvae during 3 developmental stages: pre-flexion (from 3 to $25 \mathrm{dph}$ at 13 and $15^{\circ} \mathrm{C}$ and from 3 to $20 \mathrm{dph}$ at $17^{\circ} \mathrm{C}$ ) and post-flexion $\left(25\right.$ to $50 \mathrm{dph}$ at $15^{\circ} \mathrm{C}$ and 20 to $50 \mathrm{dph}$ at $\left.17^{\circ} \mathrm{C}\right)$ and after caudal fin formation $\left(40 \mathrm{dph}\right.$ at $15^{\circ} \mathrm{C}$ and $50 \mathrm{dph}$ at $17^{\circ} \mathrm{C}$ ). MAPS: modal action patterns

\begin{tabular}{|c|c|c|c|c|c|c|c|c|}
\hline \multirow{2}{*}{ Developmental stage } & \multirow{2}{*}{ MAPS } & \multirow{2}{*}{ Temperatures $\left({ }^{\circ} \mathrm{C}\right)$} & \multirow[t]{2}{*}{$\mathrm{df}$} & \multicolumn{2}{|c|}{$\longrightarrow \mathrm{p}$-value -} & \multirow[t]{2}{*}{$F$} & \multirow{2}{*}{$\rho$} & \multirow[t]{2}{*}{$\mathrm{R}^{2}$} \\
\hline & & & & Intercept & Slope & & & \\
\hline \multirow[t]{12}{*}{ Pre-flexion } & SWI & 13 and 15 & 1 & $<0.001$ & 0.358 & 262 & $<0.001$ & 0.39 \\
\hline & & 13 and 17 & 1 & $<0.001$ & $<0.001$ & 270 & $<0.001$ & 0.44 \\
\hline & & 15 and 17 & 1 & $<0.001$ & $<0.001$ & 270 & $<0.001$ & 0.42 \\
\hline & Orientations & 13 and 15 & 1 & 0.004 & $<0.001$ & 190 & $<0.001$ & 0.31 \\
\hline & & 13 and 17 & 1 & 0.193 & $<0.001$ & 270 & $<0.001$ & 0.44 \\
\hline & & 15 and 17 & 1 & 0.390 & $<0.001$ & 183 & $<0.001$ & 0.33 \\
\hline & Attacks & 13 and 15 & 1 & $<0.001$ & $<0.001$ & 140 & $<0.001$ & 0.25 \\
\hline & & 13 and 17 & 1 & 0.047 & $<0.001$ & 229 & $<0.001$ & 0.41 \\
\hline & & 15 and 17 & 1 & 0.130 & 0.007 & 115 & $<0.001$ & 0.23 \\
\hline & Success & 13 and 15 & 1 & 0.366 & $<0.001$ & 44 & $<0.001$ & 0.09 \\
\hline & & 13 and 17 & 1 & 0.026 & 0.042 & 34 & $<0.001$ & 0.09 \\
\hline & & 15 and 17 & 1 & 0.262 & 0.001 & 36 & $<0.001$ & 0.09 \\
\hline \multirow[t]{4}{*}{ Post-flexion } & SWI & 15 and 17 & 1 & $<0.001$ & $<0.001$ & 26 & $<0.001$ & 0.06 \\
\hline & Orientations & 15 and 17 & 1 & $<0.001$ & $<0.001$ & 59 & $<0.001$ & 0.13 \\
\hline & Attacks & 15 and 17 & 1 & $<0.001$ & $<0.001$ & 70 & $<0.001$ & 0.15 \\
\hline & Success & 15 and 17 & 1 & $<0.001$ & $<0.001$ & 42 & $<0.001$ & 0.09 \\
\hline \multirow[t]{4}{*}{ Caudal fin formation } & SWI & 15 and 17 & 1 & 0.205 & 0.310 & 5 & $<0.001$ & 0.02 \\
\hline & Orientations & 15 and 17 & 1 & 0.027 & 0.047 & 3 & 0.017 & 0.01 \\
\hline & Attacks & 15 and 17 & 1 & 0.010 & 0.014 & 3 & 0.033 & 0.01 \\
\hline & Success & 15 and 17 & 1 & 0.175 & 0.136 & 2 & 0.058 & 0.007 \\
\hline
\end{tabular}



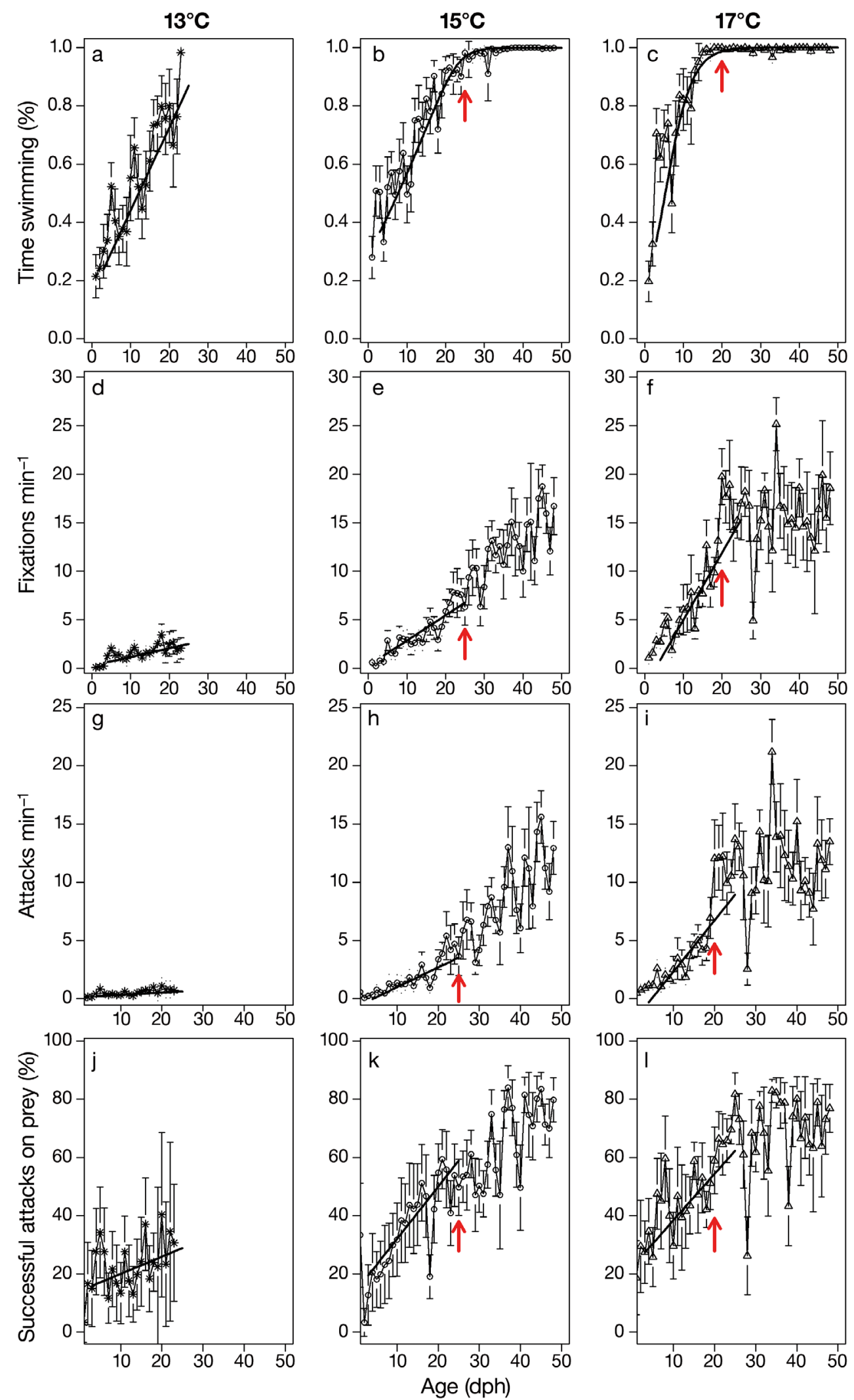

Fig. 4. Mean \pm 0.95 confidence interval bars of the $(\mathrm{a}, \mathrm{b}, \mathrm{c})$ time spent swimming, $(\mathrm{d}, \mathrm{e}, \mathrm{f})$ frequency of fixations or orientations, $(\mathrm{g}, \mathrm{h}, \mathrm{i})$ frequency of lunges during a $60 \mathrm{~s}$ period of observation throughout larval ontogeny of Sardina pilchardus and $(\mathrm{j}, \mathrm{k}, \mathrm{l})$ percentage of successful attacks on prey of larvae reared with high prey concentrations and at 3 different temperatures: 13, 15 and $17^{\circ} \mathrm{C}$. Red arrows represent the timing when notochord flexion is complete. Parameters of the linear and logistic regressions are provided in Tables $5 \& 7$ 
Table 7. Results of the Richard's logistic regression of the effect of temperature and age (d post hatch, dph) on the percentage of time spent swimming by Sardina pilchardus larvae from 3 to $50 \mathrm{dph}$ at 15 and $17^{\circ} \mathrm{C}$

\begin{tabular}{|lcc|}
\hline Parameter & $15^{\circ} \mathrm{C}$ & $17^{\circ} \mathrm{C}$ \\
\hline Bottom asymptote & -1.1 & 0 \\
Top asymptote & 1 & 1 \\
Inflexion point at $(x, y)$ & $14.7,0.7$ & $5.3,0.5$ \\
Goodness of fit & 0.90 & 0.93 \\
SE & 0.47 & 0.42 \\
$50 \%$ activity & 7.7 & 5.3 \\
\hline
\end{tabular}

During the post-flexion stage, foraging parameters were higher for larvae reared at $17^{\circ} \mathrm{C}$ when compared to those reared at $15^{\circ} \mathrm{C}$ (Tables 5 \& 6). Time spent swimming did not increase significantly for larvae reared at $17^{\circ} \mathrm{C}$ after flexion, contrary to those reared at $15^{\circ} \mathrm{C}$, for which there was a slight but significant increase (Table 5). Orientations and attacks on prey as well as successful attacks on prey increased with age for larvae reared at 15 and $17^{\circ} \mathrm{C}$ during the post-flexion stage and were significantly higher at $17^{\circ} \mathrm{C}$ (Tables $5 \& 6$ ), and at the temperature when the flexion of the notochord was complete corresponded to a sharp increase in foraging ability of the larvae reared at $17^{\circ} \mathrm{C}$, contrasting to larvae reared at $15^{\circ} \mathrm{C}$, for which the increase in foraging was less abrupt.

After the caudal fin formation (30 and $40 \mathrm{dph}$ for larvae reared at 17 and $15^{\circ} \mathrm{C}$, respectively), time spent swimming did not increase significantly for larvae reared at 15 and $17^{\circ} \mathrm{C}$ as it was near to maximum. All foraging parameters were significantly higher at $17^{\circ} \mathrm{C}$ when compared to those of larvae reared at $15^{\circ} \mathrm{C}$ after caudal fin formation. Moreover, foraging parameters such as orientations and attack on prey significantly increased with age for larvae reared at $15^{\circ} \mathrm{C}$, contrary to larvae reared at $17^{\circ} \mathrm{C}$, for which these rates did not increase with age after the caudal fin formation (Tables $5 \& 6$ ). The percentage of successful attacks on prey did not increase with age after the caudal fin formation for larvae reared at 15 and $17^{\circ} \mathrm{C}$ (Fig. 4, Tables 5 \& 6).

\section{DISCUSSION}

Despite the ecological and commercial importance of sardines and anchovies in the world's oceans, controlled laboratory studies on the growth, feeding and mortality of any life stage of these fishes are rare (Peck et al. 2013). This study is the first to examine the effect of temperature on the growth, mortality and foraging behaviour of European sardine larvae reared from hatch through first-feeding and well into the exogenous feeding period. Our results highlight the controlling role that temperature plays on larval development, growth and feeding performance.

After fertilizing and incubating eggs at the same temperature, the yolk-sac period of sardine larvae described in Blaxter (1969) and Miranda et al. (1990) was 2 to $5 \mathrm{~d}$ between 20 and $10^{\circ} \mathrm{C}$, respectively, which agrees with the observations in the present study. Although the rate of embryonic development increased with increasing temperature, the survival of unfed larvae was highest within a more narrow range of temperatures typically occurring during the spawning period of sardine in Iberian Atlantic waters. Time needed from hatch until dead from starvation was slightly lower in the present study than reported for larvae collected from northwestern Iberia (Miranda et al. 1990) and slightly longer than reported for larvae collected from the English Channel (Blaxter 1969). Part of this variation can be the result of physiological adaptations of marine fish embryos to prevailing local conditions for populations living in different latitudes, as shown by Tarifeño et al. (2008) for Peruvian anchovies.

The growth pattern of unfed sardine larvae was similar to that described by Blaxter (1969). Larvae increased in length with age until the yolk reserves were exhausted, when substantial decreases in length subsequently occurred. This decrease in mean length was particularly marked at higher temperatures. At $22^{\circ} \mathrm{C}$, sardine larvae growth was practically null immediately after the endogenous feeding period, and larvae died sooner than at 13 to $17^{\circ} \mathrm{C}$, probably as the result of a sharp increase in metabolic demands with the increase in temperature. For the 13$17^{\circ} \mathrm{C}$ range, similar to that experienced by sardines spawning off Iberia, there were no relevant differences in the endurance to starvation of the larvae, although the decline in larval mean size for unfed larvae was steeper at $17^{\circ} \mathrm{C}$. It appears, then, that the point of no return (when larvae will die regardless of whether prey becomes available) is overall quite similar within this temperature range (Pepin 1991).

Daily mortality was very high for the first weeks of life and then significantly decreased at 12 dph for larvae reared at 15 and $17^{\circ} \mathrm{C}$ and at $15 \mathrm{dph}$ for larvae reared at $13^{\circ} \mathrm{C}$. This decrease can be related to the beginning of the flexion of the notochord, when larvae became more efficient swimmers and foragers. There were significant differences in the daily mortality of fed larvae reared at 13,15 and $17^{\circ} \mathrm{C}$, and the 
patterns observed depended on the life stage. During the endogenous feeding period, daily mortality was higher for larvae reared at higher temperatures, but in exogenously feeding larvae, daily mortality was higher for larvae reared at the lowest temperature. Interestingly, total cumulative mortality was similar between the 3 temperatures at the end of the experimental period ( $25 \mathrm{dph}$ ). Similar results were reported for the larvae of Atlantic cod Gadus morhua (von Herbing Hunt et al. 1996), suggesting that, within a range of temperatures near the centre of the tolerance range, there is little effect of temperature on cumulative mortality. According to the authors, intrinsic factors may be the predominant agents of mortality prior to yolk-absorption, but this shifts to extrinsic (environmental) factors as the fish begin to feed. Increased mortality during the egg and yolk-sac stage is known to occur at higher temperatures (Houde 1989). Alternatively, increased larval mortality at lower temperatures after the endogenous feeding could be related to the decreased foraging and growth potential at sub-optimally cold temperatures, and consequently, larvae have the smallest size-atage (Pepin 1991).

Within the range $13-17^{\circ} \mathrm{C}$, the growth of well-fed sardine larvae increased with increasing temperature, which is in accordance with previous studies demonstrating that, within the optimal temperature range for a species, growth and development rates increase at warmer temperatures (Pepin 1991). Growth rates of small pelagic fish larvae were described to have a domed-shaped relationship with sea surface temperature (SST) (Takasuka et al. 2007), increasing up until a maximum after which they decrease with increasing temperature. According to the present results, the inflexion point when growth starts to decrease with increasing temperature for sardine larvae (upper thermal tolerance limit) is $>17^{\circ} \mathrm{C}$. However, the upper thermal tolerance point for egg development was not tested. Eggs were spawned and fertilized in the adult tank at $15^{\circ} \mathrm{C}$ and were collected and transferred to different test temperatures halfway through egg development. Since the thermal tolerance of eggs tends to be lower than that of larvae (Pepin 1991, Jordaan \& Kling 2003), the thermal limits of sardine egg development from fertilization is likely to have a narrower range than that shown here for the larvae. In a previous study, the broodstock fish used in the present study naturally produced eggs at 18 to $19^{\circ} \mathrm{C}$, and those eggs and larvae were reared at this (relatively warm) temperature. Despite using the same feeding protocol, no larvae survived beyond the first week, and many larvae displayed skeletal deformities, suggesting that these temperatures represent the upper lethal temperature for Iberian sardine larvae (S. Garrido unpubl. data). Thermal tolerance is expected to increase as fish grow up to the juvenile and adult stages. A recent work conducted in the Mediterranean Sea (Schismenou et al. 2016) has found that larvae occurred in areas of SST ranging from 13 to $17^{\circ} \mathrm{C}$, and a linear and positive relationship of sardine larvae growth rate was found with temperature. In contrast, sardine juveniles developed in a wider range of temperatures $\left(12-27^{\circ} \mathrm{C}\right)$ and had a dome-shaped growth response, with an optimum at around $24^{\circ} \mathrm{C}$.

Temperature-specific growth rates of small pelagic fish larvae can be quite different depending upon the ecosystem/region, year and/or study (Peck et al. 2013). Optimal temperature for sardine spawning off the east Atlantic (Iberian) waters is from approximately 13 to $17^{\circ} \mathrm{C}$, with warmer waters being used at lower latitudes (off northwest Africa, $15-20^{\circ} \mathrm{C}$ ) and colder waters being utilized at higher latitudes (British Islands, $\left.10-17^{\circ} \mathrm{C}\right)($ Coombs et al. 2006). It is likely that there are local adaptations of sardine populations to prevalent environmental conditions and that populations living at higher latitudes are more tolerant to lower temperatures compared to those living at lower latitudes areas. Sundby (2000) observed that Atlantic cod stocks from the colder areas within the species distribution range tended to have increased recruitment in warmer than average years, whereas those from warmer areas within the range had increased recruitment in cooler than average years. The authors hypothesize that the causal effect of temperature on the growth and recruitment of North Atlantic cod populations can partly be the result of a direct effect by changes in physiological processes of cod and partly an indirect effect through trophic transfer and availability of prey correlated to temperature. Nevertheless, the range of temperatures that promotes high rates of larval survival and strong recruitment might be much narrower than could be inferred from the geographic extent of the species (Jordaan \& Kling 2003).

Several lines of evidence from the laboratory, such as the midpoint of the zone of thermal tolerance (Bernal et al. 2008), showed that sardine eggs do not hatch at $10^{\circ} \mathrm{C}$, and results mentioned above showed that larvae hatching from eggs reared at $>18^{\circ} \mathrm{C}$ did not survive beyond the first week ( $\mathrm{S}$. Garrido unpubl. data). Evidence from the field, such as the median temperature experienced in spawning areas (Coombs et al. 2006) and the tendency for recruitment to be maximized at intermediate tem- 
peratures (S. Garrido et al. unpubl.), suggest that the optimal temperature for Atlanto-Iberian sardine during early life would be around $15^{\circ} \mathrm{C}$. In our experiments, however, early sardine larvae had high growth capacity at temperatures $>15^{\circ} \mathrm{C}$. This apparent mismatch between temperatures of spawning and of maximum larval growth has also been described for cod (Jordaan \& Kling 2003), where peak spawning occurs at $5-7^{\circ} \mathrm{C}$, but larvae are able to grow and survive at $>15^{\circ} \mathrm{C}$. Since standard and active metabolic rates, and consequently prey requirements, of ectotherms are positively related to temperature, constrains in the food supply will eventually reduce the temperature at which growth performance is maximized (Brett 1979, Jobling 1997, Sundby 2000, Jordaan \& Kling 2003). When facing restricted feeding conditions, larvae will die faster at higher temperatures (Laurel \& Blood 2011). Thus, in the wild, fish growth tends to be maximized at temperatures a few degrees lower than those at which food consumption is maximal (e.g. Jobling 1993). Furthermore, other researchers have suggested that having maximum field abundance at temperatures slightly colder than optimal temperature for growth is a form of metabolic insurance (Thomas et al. 2012), since thermal windows for performance are shifted to the right, making critical (intolerably warm) temperatures often only a few degrees above optimum growth temperatures (Pörtner \& Peck 2010, Boersma et al. 2016). For these reasons, it is not surprising that European sardine larvae tend to occur most frequently in field samples collected in slightly colder waters (Coombs et al. 2006) than their laboratory maximum $\left(17^{\circ} \mathrm{C}\right.$, when larvae grew more than those reared at $15^{\circ} \mathrm{C}$ and had similar cumulative mortalities, as opposed to those reared at $18^{\circ} \mathrm{C}$, as mentioned above). In our experiments, larvae were exposed to optimal feeding conditions that may be rarely encountered in the sea. Furthermore, seawater temperature often covaries with food availability (Rankin \& Sponaugle 2011); therefore, the indirect effect of temperature on availability of prey may be just as important as the direct physiological effect of temperature on the foraging and growth capacity of fish (Loeng 1989). In regions where temperatures are higher than in the Ibero-Atlantic area, such as the Mediterranean Sea, food availability probably plays a pivotal role in determining larval survival. In the Mediterranean Sea, sardine spawns preferentially at $12-14^{\circ} \mathrm{C}$, but spawning also occurs up to $19^{\circ} \mathrm{C}$ (Palomera et al. 2007). For larvae developing in that area under warmer conditions, growth was described to be higher when compared to the western Iberia, and larval condition was strongly dependent of high food availability (Catalán et al. 2006).

Elevated temperatures can accelerate the timing of ontogenetic development more than the rate of growth (Fuiman et al. 1998). Not only did larvae grow faster at higher temperatures, but ontogenetic development also occurred sooner and at smaller sizes. The timing of morphological development of sardine larvae varied inversely with temperature, but as observed by Fuiman et al. (1998), not every event was equally accelerated by temperature. In general, fin formation occurred earlier and at smaller sizes with increasing temperature, and this was translated into higher foraging abilities at age for larvae growing in higher temperatures. The time spent swimming and the foraging behaviour of sardine larvae increased with age/size. The increase in the frequency of prey capture with age/size is a consequence of larger larvae swimming faster (Silva et al. 2014) and being able to capture prey within a wider size range (Caldeira et al. 2014). By being able to select larger prey, larger larvae maximize the net rate of energy gain, because, all other things being equal, larger prey yield more energy per unit effort. The swimming activity and the foraging performance of sardine larvae both increased with increasing temperature (from 13 to $17^{\circ} \mathrm{C}$ ), and the effect of temperature was more marked on prey pursuit and prey attack frequencies. Larvae spend all their time swimming (at least during daylight hours) when notochord flexion begins and dorsal fin starts to form (Fig. 4, Table 4). The ontogenetic increase in the swimming ability of sardine larvae matches the timing of notochord flexion (Silva et al. 2014), coinciding with the beginning of the caudal fin formation and development of the swim bladder (Santos et al. 2007). This ontogenetic event also marks the time when foraging abilities (number of orientations and attacks on prey and percent success in capturing prey) sharply increased, which was more abrupt for larvae reared at $17^{\circ} \mathrm{C}$ than for larvae reared at $15^{\circ} \mathrm{C}$. After the caudal fin formation, there was no increase in larval swimming and foraging with age for larvae reared at $17^{\circ} \mathrm{C}$, supporting the idea that this is an important developmental milestone for fish, marking a clear separation of higher abilities (Gibb et al. 2006, Somarakis \& Nikolioudakis 2010, Kopf et al. 2014). These morphological changes occurred approximately $10 \mathrm{~d}$ earlier at $17^{\circ} \mathrm{C}$ rather than at $13^{\circ} \mathrm{C}$. Earlier improvement of swimming performance for larvae growing at higher temperatures is not only important for the capacity to conduct diel vertical migration influencing advective 
transport patterns but also for the ability to successfully forage and escape predators, coinciding with the timing when fish start the schooling behaviour (Somarakis \& Nikolioudakis 2010). At this stage, larvae are described to switch from an anguilliform to a subcarangiform swimming style (Batty 1984), and this corresponds to the time when substantial endurance swimming is developed (Clark et al. 2005). Moreover, temperature can affect the phenotype of the larvae under development, altering the relative timing of development of the different tissues and organs (such as muscles and bones) during very early ontogeny (Johnston et al. 2001, Koumoundouros et al. 2009 and references within). This has been demonstrated in other clupeids such as Atlantic herring (Moyano et al. 2016) as well as in European sardine, where larvae growing in higher temperatures had a higher recruitment of muscle fibres compared to conspecifics given similar feeding conditions at lower temperatures (Catalán et al. 2004). The temperature experienced during the embryonic and early larval stages, therefore, can have profound consequences for the survival of larvae and later stages (Koumoundouros et al. 2009).

In contrast to the sardine larvae studied here, Hunter (1972) reported no effect of age on the percentage of successful attacks (average $52 \%$ ) in the larvae of northern anchovy Engraulis mordax. Moreover, through an age of $30 \mathrm{dph}$, those larvae displayed a mean \pm SD of $1.75 \pm 0.20$ feeding strikes $\mathrm{min}^{-1}$ at $17-18^{\circ} \mathrm{C}$ (Hunter 1972), which is similar to what was observed in the present study at $13^{\circ} \mathrm{C}$ $(1.4 \pm 1.8)$ but markedly lower than feeding strike frequencies observed at temperatures of $15^{\circ} \mathrm{C}(3.7 \pm$ $\left.5.45 \mathrm{~min}^{-1}\right)$ or $17^{\circ} \mathrm{C}\left(7.1 \pm 6.75 \mathrm{~min}^{-1}\right)$, which suggests a higher foraging activity for European sardine larvae.

The substantial enhancement of foraging at warmer temperatures might not necessarily result in enhanced larval growth, since metabolic costs also increase with increased swimming activity, which could potentially offset any gains due to increased feeding success (Checkley 1984, Kiørboe et al. 1987). It is worth noting, however, that the different components of each foraging event have different expenditures of energy, e.g. swimming speeds during attack result in specific metabolic rates that are twice those in pursuit bursts (Hunt von Herbing et al. 1996). Therefore, increased temperature may have translated into only marginally higher energy expenditures and only slight reductions in growth efficiency, because pursuit success also increased with increasing temperature.
The response to temperature of different biological processes is not necessarily similar. The temperatures at which ingestion rate, growth rate and conversion efficiency are maximized can be different (Jobling 1993, 1997). Larvae experiencing lower temperatures will have longer stage durations which lengthens the period of time when they are most vulnerable to predators, whereas larvae at warmer temperatures will have to ingest more prey per unit growth, and these higher costs decrease the time needed for individuals to reach the point-of-noreturn in poor prey fields (Pepin 1991). At the same time, larvae experiencing warmer temperatures may experience higher potential predation mortality through both increased encounter rates with predators and reduced energy available for predator evasion (Litvak \& Leggett 1992, Lankford et al. 2001, Jordaan \& Kling 2003). A recent modelling study suggested that benefits of faster growth at warmer temperature can be offset by increases in predator feeding rates (Akimova et al. 2016). As a result of these associated trade-offs, the temperature at which maximum daily growth is realized (Otterlei et al. 1999, Steinarsson \& Björnsson 1999) may not be the optimal temperature for survival. Additionally, density-dependent effects may impede the benefits of increased growth rates by increasing competition for food in the wild, as described for cod (Holt \& Jørgensen 2014).

The survival of sardine larvae and their potential for recruitment will depend on the environmental conditions and how these conditions affect the growth and mortality rates of the eggs and larvae. Temperature has been involved as a major factor in both yearto-year fluctuations and long-term trends in fish populations (e.g. Loeng 1989). In our experiments with well-fed sardine larvae, growth rate increased with increasing temperature. This higher growth was associated with large increases in foraging activity, therefore implying that sardine larvae will depend on high prey concentrations in order to survive at high temperatures. Sardines have an extensive distribution range from the waters off Ireland and the UK to northwestern Africa, experiencing a relatively broad temperature range. It is likely that the selective pressures acting to limit productivity at the higher latitudinal limit of distribution are more likely related to temperatures falling below tolerance thresholds of the species, whereas food availability probably plays a pivotal role influencing the upper energetically affordable tolerance limit of temperatures at the lower latitudinal limit. Therefore, future studies examining the influence of temperature on 
the growth and survival of sardine larvae should take into account the combined influence of temperature and food availability, particularly if projections of global warming are associated with changes in plankton productivity.

Acknowledgements. This work was supported by Fundação para a Ciência e Tecnologia (FCT) as part of the project VITAL (Vital rates of pelagic fish larvae PTDC/MAR/ 111304/2009). Project MODELA (PTDC/MAR/098643/2008) partially supported this work. S.G. was partially supported by FCT through 2 post-doctoral fellowships (SFRH/BPD/ 38332/2007 and SFRH/BPD/105419/2014). The microalgae Rhodomonas baltica was provided by the Assemble Program (grant 227799) funded under the European Community Research Infrastructure Action under the FP7 'Capacities'. E.S. was funded by project TOPCOP (CTM2011-23480). Thanks are due to A. Teodósio (CCMAR, Univ. Algarve) and all the team of the Oceanário de Lisboa for their collaboration as team of project VITAL. This work contributes to project UID/Multi/04326/2013 from the Portuguese Foundation for Science and Technology (FCT).

\section{LITERATURE CITED}

Akimova A, Hufnagl M, Kreus M, Peck MA (2016) Modeling the effects of temperature on the survival and growth of North Sea cod (Gadus morhua) through the first year of life. Fish Oceanogr 25:193-209

Barlow GW (1968) Ethological units of behavior. In: Ingle DJ (ed) The central nervous system and fish behavior. University of Chicago Press, Chicago, IL, p 217-232

- Batty RS (1984) Development of the swimming movements and musculature of larval herring (Clupea harengus). J Exp Biol 110:217-229

Bernal M, Ibaibarriaga L, Lago de Lanzós A, Lonergan M and others (2008) Using multinomial models to analyse data from sardine egg incubation experiments; a review of advances in fish egg incubation analysis techniques. ICES J Mar Sci 65:51-59

Blaxter JHS (1969) Experimental rearing of pilchard larvae, Sardina pilchardus. J Mar Biol 49:557-575

- Blaxter JHS (1991) The effect of temperature on larval fishes. Neth J Zool 42:336-357

> Boersma M, Grüner N, Signorelli NT, González PM, Peck MA, Wiltshire K (2016) Projecting effects of climate change on marine systems: Is the mean all that matters? Proc R Soc Lond B 283:20152274

Brett JR (1979) Environmental factors and growth. In: Hoar WS, Randall DJ, Brett JR (eds) Fish physiology. Academic Press, New York, NY, p 599-675

Caldeira C, Santos AMP, Ré P, Peck MA, Saiz E, Garrido S (2014) Effect of prey concentration on ingestion rates of European sardine Sardina pilchardus larvae in the laboratory. Mar Ecol Prog Ser 517:217-228

Catalán IA, Johnston IA, Olivar MP (2004) Seasonal differences in muscle fibre recruitment of pilchard larvae in the north-western Mediterranean. J Fish Biol 64:1605-1615

Catalán IA, Olivar MP, Palomera I, Berdalet E (2006) Link between environmental anomalies, growth and condition of pilchard Sardina pilchardus larvae in the northwestern Mediterranean. Mar Ecol Prog Ser 307:219-231
Checkley DM Jr (1984) Relation of growth to ingestion for larvae of Atlantic herring Clupea harengus and other fish. Mar Ecol Prog Ser 18:215-224

Chen Y, Jackson DA, Harvey HH (1992) A comparison of von Bertalanffy and polynomial functions in modelling fish growth data. Can Fish Aquat Sci 49:1228-1235

> Clark DL, Leis JM, Hay AC, Trnski T (2005) Swimming ontogeny of larvae of four temperate marine fishes. Mar Ecol Prog Ser 292:287-300

Clarke A, Johnston NM (1999) Scaling of metabolic rate with body mass and temperature in teleost fish. J Anim Ecol 68:893-905

Coombs SH, Smyth T, Conway D, Bernal M, Stratoudakis Y, Alvarez P (2006) Spawning season and temperature relationships for sardine (Sardina pilchardus) in the eastern North Atlantic. J Mar Biol Assoc UK 86:1245-1252

Dahlke FT, Politis SB, Butts IAE, Trippel EA, Peck MA (2016) Additive genetic variation affects thermal reaction norms for embryo viability in cod, Gadus morhua. J Exp Mar Biol Ecol 474:148-155

Fuiman LA, Poling KR, Higgs DM (1998) Quantifying developmental progress for comparative studies of larval fishes. Copeia 1998(3):602-611

Gamulin T, Hure T (1955) Contribution à la connaisance de l'écologie de la ponte de la sardine (Sardina pilchardus Walb.) dans l'Adriatique. Acta Adriat 8:1-22

> Garrido S, Santos AMP, Santos A, Ré P (2009) Spatial distribution and vertical migrations of fish larvae communities off northwestern Iberia sampled with LHPR and Bongo nets. Estuar Coast Shelf Sci 84:463-475

Gibb AC, Swanson BO, Wesp H, Landels C, Landels C, Liu C (2006) Development of the escape response in teleost fishes: Do ontogenetic changes enable improved performance? Physiol Biochem Zool 79:7-19

> Holt RE, Jørgensen C (2014) Climate warming causes lifehistory evolution in a model for Atlantic cod (Gadus morhua). Conserv Physiol 2:cou050

Houde ED (1989) Comparative growth, mortality, and energetics of marine fish larvae - temperature and implied latitudinal effects. Fish Bull 87:471-495

Hunt von Herbing I, Boutilier RG, Miyake T, Hall BK (1996) Effects of temperature on morphological landmarks critical to growth and survival in larval Atlantic cod (Gadus morhua). Mar Biol 124:593-606

Hunter JR (1972) Swimming and feeding behavior of larval anchovy Engraulis mordax. Fish Bull 70:821-838

ICES (2014) Report of the Working Group on Southern Horse Mackerel, Anchovy and Sardine (WGHANSA). 20-25 June 2014, Copenhagen, Denmark. ICES CM 2014/ACOM:16

Jobling M (1993) Bioenergetics: feed intake and energy partitioning. In: Rankin CJ, Jensen FB (eds) Fish ecophysiology. Chapman \& Hall, London, p 1-44

Jobling M (1997) Temperature and growth: modulation of growth rate via temperature change. In: Wood CM, McDonald DG (eds) Global warming: implications for freshwater and marine fish. Cambridge University Press, Cambridge, p 223-254

Johnston IA, Vieira VLA, Temple GK (2001) Functional consequences and population differences in the developmental plasticity of muscle to temperature in Atlantic herring Clupea harengus. Mar Ecol Prog Ser 213:285-300

Jordaan A, Kling LJ (2003) Determining the optimal temperature range for Atlantic cod (Gadus morhua) 
during early life. In: Browman HI, Skiftesvik AB (eds) The big fish bang. Institute of Marine Research, Bergen, p 45-62

Kiørboe T, Munk P, Richardson K (1987) Respiration and growth of larval herring Clupea harengus: relation between specific dynamic action and growth efficiency. Mar Ecol Prog Ser 40:1-10

Kopf SM, Humphries P, Watts RJ (2014) Ontogeny of critical and prolonged swimming performance for the larvae of six Australian freshwater fish species. J Fish Biol 84: 1820-1841

Koumoundouros G, Ashton C, Sfakianakis DG, Divanach P, Kentouri M, Anthwal N, Stickland NC (2009) Thermally induced phenotypic plasticity of swimming performance in European sea bass Dicentrarchus labrax juveniles. J Fish Biol 74:1309-1322

Lankford TE Jr, Billerbeck JM, Conover DO (2001) Evolution of intrinsic growth and energy acquisition rates. II. Trade-offs with vulnerability to predation in Menidia menidia. Evolution 55:1873-1881

Laurel BJ, Blood DM (2011) The effects of temperature on hatching and survival of northern rock sole larvae (Lepidopsetta polyxystra). Fish Bull 109:282-291

Litvak MK, Leggett WC (1992) Age and size-selective predation on larval fishes: the bigger-is-better hypothesis revisited. Mar Ecol Prog Ser 81:13-24

> Loeng H (1989) The influence of temperature on some fish population parameters in the Barents Sea. J Northwest Atl Fish Sci 9:103-113

Martin P, Bateson P (1993) Measuring behavior: an introductory guide. Cambridge University Press, Cambridge

- Miranda A, Cal RM, Iglesias J (1990) Effect of temperature on the development of eggs and larvae of sardine Sardina pilchardus Walbaum in captivity. J Exp Mar Biol Ecol 140:69-77

> Moyano M, Illing B, Peschutter P, Huebert KB, Peck MA (2016) Thermal impacts on the growth, development and ontogeny of critical swimming speed in Atlantic herring larvae. Comp Biochem Physiol A Mol Integr Physiol 197: 23-34

> Otterlei E, Nyhammer G, Folkvord A, Stefansson SO (1999) Temperature- and size-dependent growth of larval and early juvenile Atlantic cod (Gadus morhua): a comparative study of Norwegian coastal cod and northeast Artic cod. Can J Fish Aquat Sci 56:2099-2111

> Peck MA, Reglero P, Takahashi M, Catalán IA (2013) Life cycle ecophysiology of small pelagic fish and climatedriven changes in populations. Prog Oceanogr 116: $220-245$

> Pepin P (1991) Effect of temperature and size on development, mortality, and survival rates of the pelagic early life history stages of marine fish. Can J Fish Aquat Sci 48: 503-518

Pörtner HO, Peck MA (2010) Climate change effects on fishes and fisheries: towards a cause-and-effect understanding. J Fish Biol 77:1745-1779

Rankin TL, Sponaugle S (2011) Temperature influences

Editorial responsibility: Stylianos Somarakis, Heraklion, Greece selective mortality during the early life stages of a coral reef fish. PLOS ONE 6:e16814

- Relvas P, Luis J, Santos AMP (2009) The importance of the mesoscale in the decadal changes observed in the Northern Canary upwelling system. Geophys Res Lett 36: L22601

> Rijnsdorp AD, Peck MA, Engelhard GH, Möllmann C, Pinnegar JK (2009) Resolving the effect of climate change on fish populations. ICES J Mar Sci 66:1570-1583

> Santos AMP, Chícharo A, Dos Santos A, Moita T, Oliveira PO, Peliz A, Ré P (2007) Physical-biological interactions in the life history of small pelagic fish in the western Iberia upwelling ecosystem. Prog Oceanogr 74:192-209

Schismenou E, Palmer M, Giannoulaki M, Alvarez I, Tsiaras K, Triantafyllou G, Somarakis S (2016) Seasonal changes in otolith increment width trajectories and the effect of temperature on the daily growth rate of young sardines. Fish Oceanogr 25:362-372

Silva A, Santos MB, Caneco B, Pestana G, Porteiro C, Carrera P, Stratoudakis Y (2006) Temporal and geographic variability of sardine maturity at length in the northeastern Atlantic and the western Mediterranean. ICES J Mar Sci 63:663-676

Silva L, Faria AM, Teodósio MA, Garrido S (2014) Ontogeny of swimming behaviour in sardine Sardina pilchardus larvae and effect of larval nutritional condition on critical speed. Mar Ecol Prog Ser 504:287-300

Somarakis S, Nikolioudakis N (2010) What makes a late anchovy larva? The development of the caudal fin seen as a milestone in fish ontogeny. J Plankton Res 32:317-326

Steinarsson A, Björnsson B (1999) The effects of temperature on growth and mortality of cod larvae. J Fish Biol 55: 100-109

Stratoudakis Y, Coombs S, de Lanzós AL, Halliday N and others (2007) Sardine (Sardina pilchardus) spawning seasonality in European waters of the northeast Atlantic. Mar Biol 152:201-212

Sundby S (2000) Recruitment of Atlantic cod stocks in relation to temperature and advection of copepod populations. Sarsia 85:277-298

Takasuka A, Oozeki Y, Aoki I (2007) Optimal growth temperature hypothesis: Why do anchovy flourish and sardine collapse or vice versa under the same ocean regime? Can J Fish Aquat Sci 64:768-776

> Tarifeño E, Carmona M, Llanos-Rivera A, Castro LR (2008) Temperature effects on the anchoveta Engraulis ringens egg development: Do latitudinal differences occur? Environ Biol Fishes 81:387-395

Thomas MK, Kremer CT, Klausmeier CA, Litchman E (2012) A global pattern of thermal adaptation in marine phytoplankton. Science 338:1085-1088

Whitehead PJP (1985) Clupeoid fishes of the world. An annotated and illustrated catalogue of the herrings, sardines, pilchards, sprats, anchovies and wolfherrings. Part 1 - Chirocentridae, Clupeidae and Pristigasteridae. FAO Fish Synop No. 125, Vol 7. FAO, Rome. ftp://ftp.fao.org/ docrep/fao/009/ac482e/ac482e00.pdf

Submitted: January 5, 2016; Accepted: August 25, 2016

Proofs received from author(s): October 7, 2016 